8. Reybrouck, M., Podlipniak, P., Welch, D. (2019). Music and Noise: Same or Different? What Our Body Tells Us. Frontiers in Psychology, 10, pp. 1-13 [in English]. https://doi.org/10.3389/fpsyg.2019.01153.

9. Tukova, I. (2020). Treatment of Sound in Contemporary Art Music (at the Examples of Works by Ukrainian Composers). Proceedings of the 4th International Conference on Art Studies: Science, Experience, Education (ICASSEE 2020), 469, pp. 269-276 [in English]. https://doi.org/10.2991/ assehr.k.200907.048.

УДК 780.614.1:781.22]:78.049(477)«19/20»

DOI https://doi.org/10.31723/2524-0447-2020-31-2-23

Ксенія Дмитрівна Сліпченко

ORCID: 0000-0001-5226-5930

аспірантка кафедри інтерпретології та аналізу музики

Харківського національного університету мистецтв імені I. П. Котляревського

ksuslipchenko256@gmail.com

\title{
НОВІ ВИМІРИ ЗВУКООБРАЗУ ДОМРИ В УКРАЇНСЬКІЙ МУЗИЦІ ОСТАННЬОЇ ЧВЕРТІ ХХ - ПЕРШОÏ ЧВЕРТІ ХХІ СТОЛІТТЯ
}

Мета дослідження - виявити виміри звукообразу домри в українській музиці останньої чверті XX - першої чверті ХХІ століття на прикладi «Зозулі» для домри соло Л. Матвійчук, «Дощика» для домри соло B. Матряшина, Концертного триптиха «В наслідування іспанському» для домри та фортепіано А. Білошицького, дитячої сюїти «Хоббіт, або Туди й Звідти» для домри та фортепіано В. Матряшина, «Передзвонів» та «Мерехтливого звуку» для домри соло О. Олійника. Методологія дослідження спирається на взаємодію компаративного, системного, жанрово-стильового та семіотичного підходів. Наукова новизна дослідження полягає у визначенні етапів становлення домри, виявленні засобів для розширення ї̈ звукозображувальної палітри, ролі сонорних можсливостей інструменту та диференціації його звукових образів. Висновки. Нами було запропоновано три етапи становлення домри, які ми окреслили як «фольклористичний», етап «академізаиї» та останній етап - «із сучасними тенденціями останньої чверті XX - першої чверті XXI століття». Також у дослідженні було виявлено, що композитори розширюють виражальну палітру домри через наслідування інших інструментів,

(с) Сліпченко К. Д., 2020 
втілення природних та фізичних явищ, звукозображання фантастичних персонажів, подій та стилізацію кельтської та іспанської музики на домрі. Так, наприклад, наслідування інших інструментів відбилось у використанні запозичених та ударно-шумових прийомів. Втілення природних та фізичних явищ стає можливим за допомогою наслідування образу зозулі, а образ дощу реалізується через неперервне оstinato та залучення комплексу різноманітних прийомів. Втілення дзвонності стає можлливим не тільки завдяки використанню кварто-квінтових ходів y мелодії, але й втіленню різновидів дзвоніння та імітації дзвіночків. Стилізація кельтської та іспанської музики відбувається за рахунок тяжіння мелодії до певних тональних центрів, використання різноманітних ладів та наслідування інструментів. Паралельно з цим розширюються типи трактовки тембру домри від колористичного до сонорики та сонористики. Як наслідок, ми виявили, що звукообраз домри може бути сонорний, колористичний, ударний, кельтський, іспанський, дзвонний та «мерехтливий».

Ключові слова: домра, звукообраз, сонорика, колористика, фламенко, кельтська музика, іспанська музика, прийоми звуковидобування.

Slipchenko Kseniia Dmytrivna, Postgraduate Student at the Department of Interpretology and Analysis of Music of the Kharkiv National I. P. Kotlyarevsky University of Arts

New dimensions of domra's sound pattern in Ukrainian music in the last quarter of the $X X$ - first quarter of the $X X I$ century

Research objective. The aim of the work is to identify the dimensions of the sound pattern of domra in Ukrainian music in the last quarter of the $X X$ - first quarter of the XXI century on the example of "Cuckoo" for domra solo by L. Matviychuk, "Rain" for domra solo by V. Matryashin, concert triptych "In imitation of Spanish" for domra and piano by A. Biloshitsky, children's suite "Hobbit, or There and Back Again" for domra and piano by V. Matryashin, "Chimes" and "Shimmering sound" for domra solo by $O$. Oliynyk. The methodology of the research is based on the interaction of comparative, system, genre-style and semiotic approaches. The scientific novelty of the research consists in determining the stages of domra formation, identifying means to expand its sound-imaging palette and the role of sonorous capabilities of the instrument and differentiating its sound images. Conclusions. We proposed three stages of domra formation, which we described as "folklore", the stage of "academization" and the last stage "with modern trends of the last quarter of the XX - first quarter of the XXI century". The research also found that composers expand the expressive palette of domra by imitating other instruments, embodying natural and physical phenomena, sound representation of fantastic characters, events, and stylization of Celtic and Spanish domra music. Thus, for example, imitation of other instruments was reflected in the use of borrowed and percussive-noise techniques. The embodiment of natural and physical phenomena becomes possible by imitating the image of a cuckoo, and the image of rain is realized through continuous ostinato and the involvement of a complex of various techniques. The embodiment of ringing 
becomes possible not only through the use of quarto-fifth moves in melody, but also through the embodiment of varieties of ringing and imitation of bells. Stylization of Celtic and Spanish music occurs due to the attraction of the melody to certain tonal centers, the use of various tonalities and imitation of instruments. At the same time, the types of interpretation of the instrument's timbre are being expanded from coloristic to sonoric and sonorous. As a result, we found that domra's sound can be sonorous, coloristic, percussive, Celtic, Spanish, ringing and "shimmering".

Key words: domra, sound pattern, sonorics, coloristics, flamenco, Celtic music, Spanish music, sound-producing techniques.

Актуальність теми дослідження. Сучасний домровий репертуар постійно оновлюється, розкриваючи нові можливості домри. Так, простеживши шляхи розвитку інструмента від моменту створення до сьогодення, ми можемо виділити три етапи становлення інструменту.

Перший ми окреслили як «фольклористичний», на якому домра виступає інструментом народно-пісенної традиції. Розпочався перший етап у $1930-\mathrm{x}$ роках із моменту створення першої обробки для чотириструнної домри та фортепіано Г. Михайличенком [5, с. 5]. Другий етап - «академізації -починається з 1950-х років та пов'язаний із появою перших методик та шкіл гри. Останній етап - із сучасними тенденціями припадає на останню чверть XX - першу чверть XXI століття.

Особливе місце на третьому етапі займає використання цілої палітри колористичних засобів, яка покликана відобразити темброве різноманіття домри. Як правило, такі композиції тяжіють до сфери програмної музики, основаної на оригінальному тематизмі, що значно відходить від стереотипно фольклорного матеріалу та віддзеркалює прагнення композиторів до пошуку індивідуалізованих засобів для втілення образів, які апелюють до колористики, сонорики та сонористики. В українській музиці це відобразилось у доробку Л. Матвійчук, А. Білошицького, В. Матряшина та О. Олійника.

Мета дослідження - визначити різні типи трактовки тембру домри та виявити палітри нових звукообразів інструменту в українській музиці останньої чверті XX - першої чверті XXI століття.

Наукова новизна дослідження полягає у визначенні етапів становлення домри, виявленні засобів для розширення іiі звукозображальної палітри і ролі сонорних можливостей інструменту та диференціації його звукових образів. 
Виклад основного матеріалу. Л. Матвійчук розширює образну палітру домри через наслідування образів природи, прикладом чого є «Зозуля» для домри соло. Для передачі образу птаха використовуються натуральні та штучні флажолети, а чергування pizzicato 3 грою медіатором створює враження перегукування двох зозуль. Композиції притаманне одноголосся за винятком зв'язуючого мотиву та контрастної середини. За композицією «Зозуля» для домри соло Л. Матвійчук являє складну тричастинну форму з ознаками варіаційності.

Окрім наслідування пташиного співу, ми можемо виявити зв'язок із «Зозулею» для клавесину Л.-К. Дакена, що відобразилось у затактовій побудові мотивів, їхніх терцієвих інтонаціях та нисхідних гамоподібних тетрахордах із подальшим зупиненням на висхідній секундовій інтонації.

\section{Л.-К. Дакен. «Зозуля» для клавесину}

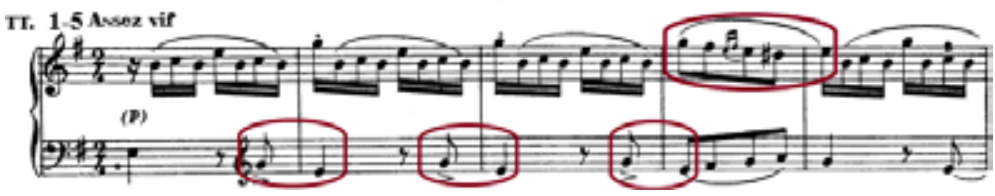

Л. Матвійчук, «Зозуля" дтя домри соло
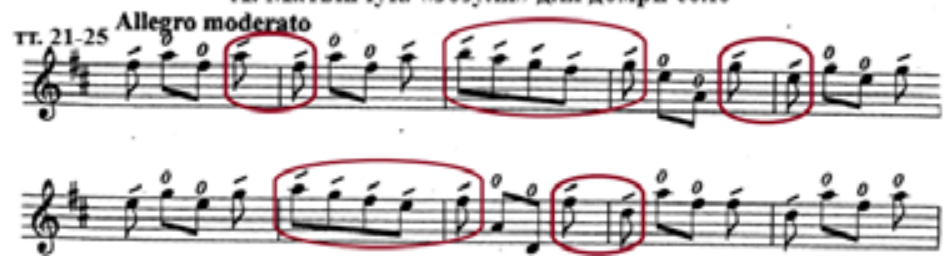

Усе вищеперераховане є своєрідним комплексом для втілення звукообразу зозулі, що дає змогу зарахувати композицію Л. Матвійчук до колористичної.

Інший зразок у звуконаслідуванні образів природи представлено в «Дощику» для домри соло В. Матряшина. Композитор-домрист використовує прийоми, які покликані урізноманітнити темброву палітру домри. В. Матряшин трансформує pizzicato правої руки в гітарне тірандо, також використовує «зрив» пальця лівої руки водночас із флажолетом, що є новим у домровому виконавстві. Новим звуковим ефектом слугує виконання «притлумленого» флажолету, який вже використано на арфі у Concerto Misterioso Леоніда Грабовського. 

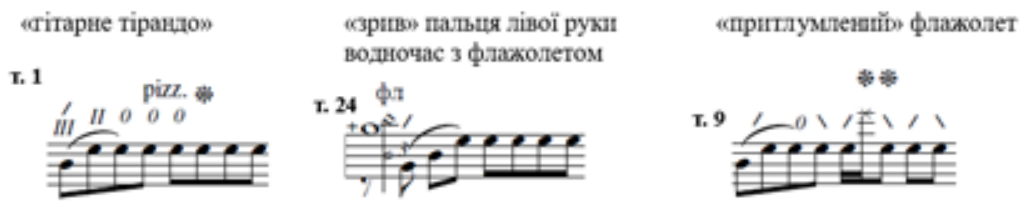

Твір має медитативний характер, чому сприяє безперервне ostinato, а мелодія змінюється лише у другій частині з появою нової теми $(b)$. За композицією твір являє собою варіаційну форму. Спектр прийомів вказує на колористику, а за жанром «Дощик» для домри соло В. Матряшина наближується до етюду.

Своєю чергою А. Білошицький наближує звукообраз домри до гітари фламенко у Концертному триптиху «B наслідування іспанському» для домри та фортепіано, який створено у 1987 році. Пізніше, у 1992 році, було зроблене авторське перекладення Триптиху для баяну, яке вийшло в німецькому виданні з трохи іншою назвою - «Im Spanish still» [2, с. 636]. 3 тих пір саме така назва закріпилась за цією композицією, та Концертний триптих більше відомий як Триптих «В іспанському стилі». Кожна частина композиції посилається на віршовані епіграфи з поезії Ф. Г. Лорки, якому і присвячено увесь цикл. Програмність сюїти полягає у використанні географічних назв у крайніх частинах, авторській вказівці щодо стилю виконання у другій та доповненні епіграфами з поезії Ф. Г. Лорки.

Цілісності концепції надає об’єднуючий образ Іспанії Андалусія. Недарма А. Білошицький саме так називає першу частину Триптиху, в якому цитує вірш Ф.Г. Лорки «Севілья». Втілення образу Андалусії отримало розвиток у другій частині циклу - «In modo di canto bailable», через введення танцю хабанера та малагенья. Так, перший переважно танцюють у портових містах, що є у достатку в Андалусії, а другий зародився у Малазі, яка також знаходиться в Андалусії. Невипадково для фіналу Триптиху вибрана назва «Triana», яка $€$ районом у Севільї, чий образ й обрамляє композицію. Також помітне тематичне та ритмічне проростання мотивів у першій та останній частині (III ч., тт. 46-55 $\approx$ I ч., тт. 24-33).

Нині Триптих А. Білошицького є єдиним прикладом відтворення образу Іспанії в домровій музиці. Враховуючи те, що стиль фламенко в принципі асоціюється з гітарою, в композиції ми зустрінемо перевагу акордової техніки, насліду- 
вання гітарного расгеадо та невеликі віртуозні фігурації, які є типовими для сольних гітарних «імпровізацій» у фламенко.

Першій частині Триптиху відповідають рядки 3 вірша «Севілья» ${ }^{1} 3$ листування колумбійського поета Х. Саламеа та Ф.Г. Лорки відомо, що іспанський поет писав ${ }^{2}:$ «<..> Андалусія неймовірна. Схід, але без отрути. Захід, але без діловитості. I кожного дня - нові дива. Ти зневажаєш ногами прекрасне тіло Півдня - а земля дякує тобі <...> [10]. Тому саме на образному розмаїтті Андалусії побудовано Концертний триптих А. Білошицького. За композицією перша частина являє просту тричастинну форму з рисами варіаційної, що відобразилось у темі та трьох варіаціях на неї.

Друга частина Триптиху має назву «In modo di canto bailable». Їй відповідають рядки з вірша Ф.Г. Лорки «Танець»³. Три теми в композиції ніби презентують три різних танця перша тема $(a)$ виконує функцію вступу, своєрідний «вихід» того, хто танцює; друга тема $(b)$ виконується в дусі хабанери, а третя (c) представляє танець малагенью. За композицією друга частина Триптиху є складною тричастинною формою.

Перша тема постає в одноголосному викладенні з висхідним рухом мелодії від I до III ступеня і навпаки, а при закінченні першої теми ми знову чуємо гітарне расгеадо (тт. 6-7). Цей прийом готує появу третьої теми в другій частині - танець малагенья, який походить саме від стилю фламенко [1, с. 53].

Друга тема написана в дусі хабанери, на що вказує не тільки авторська ремарка, але й ритмоформула теми в партії домри (тріолі чергуються з дуолями) і фортепіано (пунктирний ритм на першу долю та дві восьми на другу) та низхідний рух мелодії по напівтонах. Третя тема представляє останній різновид танцю у Триптиху - малагенью. Основні його риси представлені в розмірі (3/8), пружному ритмі в партії фортепіано та гармонічних ходах (в. $3+$ м. 3 ) у басу.

Остання частина Триптиху, в якій процитовано частину

1 В оригіналі частину вірша подано російською мовою: «... Севилья ловит медленные ритмы, и раздробясь о каменные грани, свиваются они как лабиринты, как лозы на костре ...».

2 Тут і далі переклад наш $-K$. $C$.

3 В оригіналі частину вірша подано російською мовою: «... Змея в волосах желтеет, и словно из дали дальней, танцуя, встаёт былое и бредит любовью дальней ...». 
вірша «Сутичка» ${ }^{4}$, має назву «Triana». А. Білошицький не випадково вибирає саме таку назву для останньої частини. Розташована в західній частині Севільї, Тріана виконувала оборонну функцію міста [7]. Галасливий та хаотично забудований район, який $є$ й історичним центром фламенко [1, с. 55], значно контрастує з тихішими районами Севільї [4]. Тому пояснюється характер та варіаційна форма фіналу «В наслідування іспанському» в А. Білошицького, яка представлена у вигляді невеликого вступу, теми та трьох варіацій на неї.

Фортепіанний вступ характеризується домінантовою гармонією $(h-e)$ з тяжінням до in $e$, яку заповнюють фігурації між I та II ступенем. Тема в домри заснована на висхідних тріольних фігураціях, фоном для яких є дуолі фортепіано. Таким чином, завдяки утвореній поліритмії та віртуозним пасажам домри складається образ хаотичної Тріани. При першому викладенні акордова техніка «восьмими» в партії домри надає темі речитації, а іiі мелодична вершина «коливається» між нестійкими VII та II ступенями. Проте надалі гармонічний план акордів тяжіє до тону «е» 3 подальшим дублюванням фігурацій у фортепіано.

Для втілення образу Іспанії композитор вибрав цілий спектр засобів. Так, наслідування рисам іспанського мелосу відображуються через змінні метроритмічні структури та використання циганського і фрігійського ладів. Втілення образу Тріани стає можливим через віртуозну специфіку домри та поліритмію домрово-фортепіанного дуету. Також А. Білошицький використовує іспанські танці хабанера та малагенья у другій частині Триптиху.

«В наслідування іспанському» по праву можемо зарахувати до різновиду танцювальної сюїти, в якій представлено повільний танець та мелодію, наближену до романсу (I ч. та вступ до II ч.), два іспанських танця (хабанера та малагенья у II ч.) та віртуозний фінал у дусі con brio. Таким чином, ми можемо простежити танцювальну лінію, яка «перетікає» між частинами: повільна I частина $\rightarrow$ повільний вступ до II частини $\rightarrow$ жваві іспанські танці у II частині $\rightarrow$ скерцозне закінчення II частини $\rightarrow$ віртуозний фінал.

4 В оригіналі частину вірша подано російською мовою: «В токе враждующей крови над котловиной лесною нож альбасетской работы засеребрился блесною ... Заголосили старухи в гулких деревьях сьерры. Бык застарелой распри ринулся на барьеры ...». 
Можемо зробити висновок, що Концертний триптих А. Білошицького - це єдина композиція для чотириструнної домри, в якій втілюється іспанський колорит.

Розширення образного потенціалу домри через зв'язок 3 іншим фольклором ілюструє дитяча сюїта В. Матряшина «Хоббіт, або Туди й Звідти» для домри та фортепіано, яку було створено у 2016 році за сюжетом однойменної повісті Джона Толкіена. У програмній сюїті кожна частина «представляє» одного з персонажів або якісь значущі події в повісті у хронологічній відповідності з оригіналом.

Зокрема, виникають асоціації з кельтською арфою, що відобразилось у спільній струно-щипковій природі інструментів та зручності грі при тональних центрах $d, g$ та $a$. Також аналогії з кельтською музикою підкріплюються не тільки наслідуванням арфи, але й використанням пунктирного ритму в мелодії, стрибках на великі інтервали та ostinato в акомпанементі.

Перша частина має назву «Сміливий хоббіт» та за композицією являє складну тричастинну форму з рисами варіаційності. Незважаючи на основну тональність ( $a$-moll), перша частина сюїти постійно тяжіє до тональності домінанти (e-moll). Перша частина починається фортепіанним вступом (тт. 1-4), в якому закладається грайливий та легкий характер композиції, виражений прозорою фактурою, штрихом стакато та підкресленими слабкими долями. Основну тему ( $a$, Ц. 1, тт. 5-20) викладено секвенцією, мелодія якої «кружляє» навколо основного тону.

У другій темі (b, Ц. 5-6, авторська ремарка forte, тт. 69-88) втілюється сміливий характер хоббіта. У ній партія домри викладається інтервалами, збільшується ритміка та підкреслюється кожен звук ударом вниз. У щільній фортепіанній фактурі виділяються слабкі долі та для «контрасту матеріалу» додаються невеликі фігурації. Також В. Матряшин у партії домри використовує сонористичні ефекти - стук по панциру та удари медіатором за підставкою.

Другий персонаж у сюїті - це гном Торін. 3 огляду на характеристику гномів, зрозумілий вибір помірного темпу та неспішної мелодії у другій частині «Торін $m a K^{\circ}$ ». Будова мелодії на тонічних тризвуках, затримання або «зависання» на одному звуці, повторюваність мотивів та їх стійка тональна основа відсилає до феномена «нової простоти», який виник 
у музиці другої половини XX століття [3, с. 236, 238]. Така «простота» 3'явилась на основі мінімалізму та пов'язана із зверненням композиторів до тиші, шумів, використання простих ритмічних та звуковисотних мотивів [8, с. 324]. Саме «нова простота» у третій частині циклу «Торін та $\mathrm{K}^{\circ}$ » виступає засобом для створення композиції простою та доступною мовою для дітей. За композицією «Торін та $\mathrm{K}^{\circ}$ » являє варіаційну форму у вигляді вступу, теми та трьох варіацій на неї.

Третю частину, «Ельфійська пісня», В. Матряшин стилізує під кельтську музику, що відбилось в остинатно повторюваних інтервалах та акордах у партії фортепіано, пунктирній другій темі та варіаціях на першу, стрибках на великі інтервали, які імітують діалог двох інструментів. Ельфи є персонажами кельтської міфології, тому пояснюється саме такий вибір назви і жанрової основи для третьої частини. «Ельфійська пісня» має медитативний характер та відповідає авторському тлумаченню ельфів як істот, які «<..> можуть створювати дива, <...> їхні пісні завжди лікують людей та добротно впливають на все оточуюче» [6]. Третя частина сприймається як добра та «лікувальна» пісня, яка за композицією являє складну тричастинну форму з рисами варіаційної.

В останній частині сюїти, «Свято в Eсгароті», зображуються події, де люди, ельфи та гноми подолали дракона Смауга. Тому пояснюється вибір сонатної форми, в якій протиставляються теми відповідно до сюжетної лінії. Тут продовжено стилізацію під кельтську музику, що виявляється в тонічному плані композиції та ритміці. Як зазначає у своїй статті Д. Теслов, якщо послухати «кельтських» гітаристів, ми почуємо переважно тяжіння в тональності $d, g$ та $a$ [9, с. 78]. Це зумовлено тим, що кельтська арфа та ірландська волинка - тонально-фіксовані інструменти, звідси й перевага такого тонального плану [там само]. За композицією фінал являє сонатно-варіаційну форму.

Експозицію відкриває урочистий святковий вступ (тт. 1-16) у фортепіано. Тут ми почуємо фанфари (тт. 1, 8), як у «мідних духових», імітацію оркестрового tutti та тремоло «литавр» (тт. 9-16). Тема головної партії ( $a$, А, тт. 17-24) викладається дрібною технікою з використанням другої відкритої струни $a^{2}$. Для веселої, завзятої й танцювальної мелодії характерний рух на інтервали секунди, терції та кварти. Фортепіано тут майже не чутно, а двоголосна фактура стає гармонійною «подуш- 
кою». Сполучна партія (G, тт. 72-79) викладається у фортепіано, в партії якого повертається фанфарність, урочистість та імітація оркестрового tutti.

Побічна партія представлена новою темою та варіацією на неї. У ній $(b, \mathrm{H}$, тт. 80-87) змінюється характер мелодії - він стає войовничий, шо зумовлено ходами на квінти, чергуванням прийому тремоло з підкресленими висхідними тонами, рухом мелодії вгору, та остинатними фігурами в партії фортепіано (тт. 84-87). Третя варіація ( $b^{1}, \mathrm{H}-\mathrm{I}$, тт. 88-94) є кульмінацією побічної партії, де партія супроводу викладається в унісон із домрою. Завершує побічну затримання на головному ступені $d$ в партії домри (I, тт. 92-94), який поступово опускається октавою нижче. Заключна партія (тт. 95-101) має нестійкий тональний план, для неї характерний низький діапазон та поступовий рух мелодії ущільненими акордами.

Розробка ( $a^{3}, \mathrm{~J}-\mathrm{L}$, тт. 102-143) виступає четвертою варіацією, для неї характерні мінорні тональності $(d$-moll та $a$-moll), через які виникають асоціації з драматичними подіями битви за місто. Партія фортепіано викладається різкими акцентованими акордами на сильні долі. В. Матряшин використовує поліритмію, виклад мелодії в унісон, інтонації з другої теми $(c)$, імітацію тремоло «литавр» та оркестрового tutti. Мелодія теми головної партії в домри розвивається секвенційно у висхідному русі.

Реприза скорочена та починається 3 п'ятої варіації $\left(c^{2}\right.$, M-N, тт. 144-159), в якій партія фортепіано повторює матеріал теми з центрального розділу головної партії $(c)$, а в домри мелодія підіймається октавою вище та ущільняється до триголосся в діапазоні малої октави шодо першого проведення теми ( $c$, C-D, тт. 33-49). Кода ( $a^{5}$, тт. 168-183), вона ж сьома варіація, починається двоголоссям із подальшим ущільненням до акордів. Мелодія будується на чергуванні тонів основної тональності ( $D$-dur) та ії стрімким визволенням у вигляді висхідних фігурацій від $d^{l}$ до $d^{3}$. Завершують останню частину сюїти чергування акордів у домрово-фортепіанному дуеті та їх звучання в унісон.

Сюїта В. Матряшина є єдиним зразком стилізації кельтської музики на домрі, що є досить незвичним і нетиповим та розкриває інструмент у новому образному амплуа.

О. Олійник розширяє палітру домри за рахунок ударних та шумових можливостей, які дають змогу втілювати різні образи, 
як візуальні, так й аудіальні. Програмну п’єсу «Передзвони» для домри соло було написано у 1984 році. У ній композитору-домристу вдається не тільки адаптувати ідею дзвонності для струно-щипкового інструмента, але й показати різноманітність виражального потенціалу домри. О. Олійник розширює поле дзвонного комплексудо двох видів - «дзвоніння» та «передзвін».

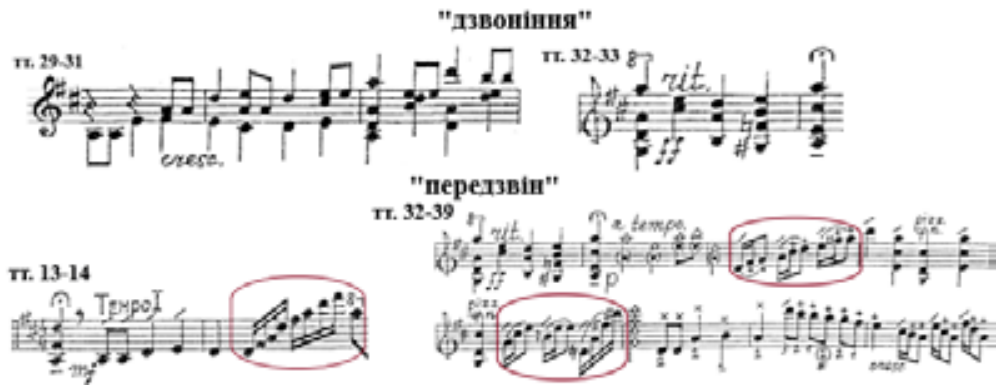

Прийоми звуковидобування спрямовані на відображення різних типів дзвонів. Так, нетремольоване низхідне glissando імітує «малі дзвони», а флажолети створюють тембровий ефект дзвіночків.

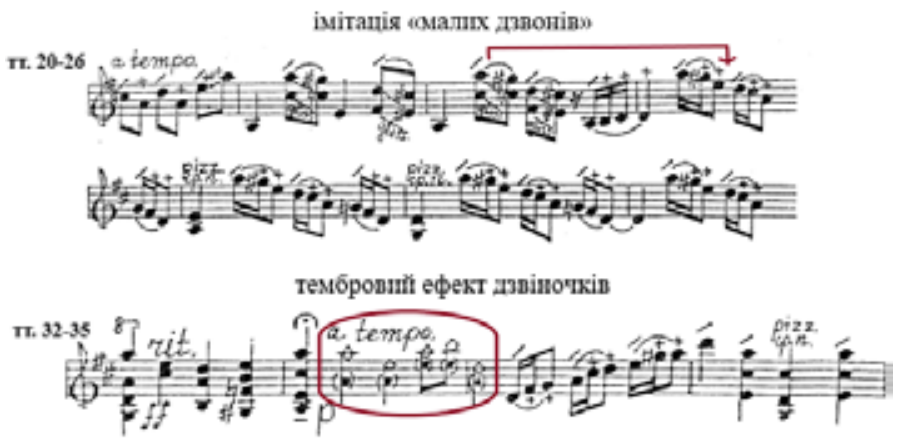

Проте на фоні яскраво-дзвонних ритмічних формул та кварто-квінтових ходів у мелодії гармонічний план п'єси виглядає досить традиційним.

Пізніше, у 1996 році, О. Олійник створює «Мерехтливий звук» для домри соло, в якому саме сонористичні прийоми відіграють провідну виражальну роль. У пошуці нових засобів тембрової виражальності О. Олійник виходить за межі темперації, використовуючи опускання та підтягування струни за 
допомогою кілка та підтягування струни пальцем лівої руки до встановленого звука відповідно до напряму стрілок.

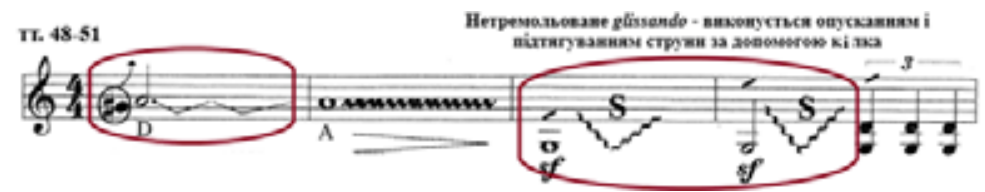

Композитор у «Мерехтливому звуці» вільно користується дванадцятитоновістю 3 помітним тяжінням in $G$. У музичній мові часто зустрічаються гармонії нетерцієвої структури - квартакорди, секундові співзвуччя, квінтакорди, а також напружені інтервальні ходи на тритон, зменшену октаву, стрибки на нони. За композицією твір являє собою складну тричастинну форму.

Сонористичні прийоми втілюються через засоби звуковидобування, кожен з яких має певний виражальний ефект, а тлумачення колористичних засобів можна виділити у блоки прийомів. Програма «Мерехтливого звуку» втілюється через використання півтонової трелі, нижній звук якої «мерехтить» на фоні відкритої струни. Новим прийомом стає виконання «слепу», а реалізація одного з різновидів glissando схожа на гітарний прийом «бенд».
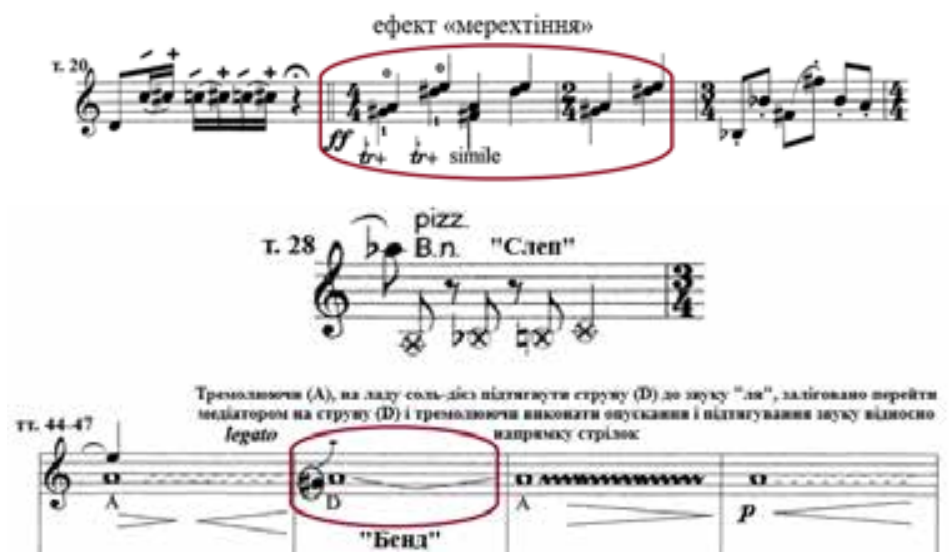

Висновки. Ми можемо побачити, що на межі XX-XXI століття виражальна палітра домри розширюється через наслідування інших інструментів, втілення природних та фізичних 
явищ, звукозображання фантастичних персонажів, подій та стилізацію кельтської й іспанської музики.

У результаті виникає ціла низка нових домрових амплуа, серед яких ми можемо зустріти сонорну домру, колористичну, ударну, «кельтську», дзвонну, домру-фламенко. Окрім цього, ми можемо почути на домрі наслідування гітари, арфи, дощу, зозулі та «мерехтливого» звучання.

Таким чином, домра вже вийшла з сприйняття іiі як сугубо фольклорного інструменту, а використання вище перерахованих принципів у композиціях не вписується в класичні закони академічної музики, корелюючи з тенденціями та композиційними техніками в музиці XX - XXI століття. «Академічні» можливості домри розширюються, а звукообразна палітра інструменту сягає від наслідування інших тембрів та адаптації їх виконавського арсеналу до сонористичних технік із використанням новітніх прийомів гри.

\section{СПИСОК ЛІТЕРАТУРИ}

1. Анди Эль Монте. Фламенко: тайны забытых легенд. Москва : Мусалаев, 2003. 194 с.

2. Бензюк О.О. Засоби створення й сприймання художнього образу в концертному триптиху «В іспанському стилі» Анатолія Білошицького. Молодий вчений. 2016. № 3. С. 634-638.

3. Двужильная И.Ф. Новая простота как феномен музыкального искусства второй половины XX в. Актуальные проблемы мировой художественной культуры : материалы международ. науч. конференц., 25-26 апреля 2002 г. Гродно, Республика Беларусь. Гродно : ГрГУ, 2002. В 2 ч. Ч. 1 С. 235-239.

4. Квартал Триана. URL: http://ourspain.ru/sevillasight/ barriodetriana.html (дата звернення 26.10.2020).

5. Костенко Н.Е. Харьковская домровая школа в контексте музыкально-исполнительской культуры Украины : дис. ... канд. мистецтвознавства : 17.00.03. Харків, 2009. 270 с.

6. Матряшин В. Детская сюита. URL: https://www.youtube.com/ watch? v=Prk4v6OWfkc (дата звернення 09.05.2020).

7. Район Триана. URL: https://www.votpusk.ru/country/dostoprim info.asp? ID=9118 (дата звернення 26.10.2020).

8. Ручкина Н.П. «Новая простота» в музыкальном искусстве XX - начала XXI века. Обсерватория культуры. 2017. Т. 14, № 3. C. $322-329$.

9. Теслов Д.В. Кельтская музыка: этапы развития в творчестве исполнителей-гитаристов. B мире науки и искусства: вопросы филологии, искусствоведения и культурологии : сборник ст. по матер. XVII междунар. науч.-практ. конф. Новосибирск : СибАК, 2012. C. $74-79$. 
10. Хорхе Саламея. URL: http://www.mir-dali.ru/library/anna-dalisalvador-dali81.html (дата звернення 23.10.2020).

\section{REFERENCES}

1. Andi, El Monte. (2003). Flamenko: tayny zabytykh legend. Moskva : Musalaev, 194 p.[in Russian].

2. Benziuk, O.O. (2016). Zasoby stvorennia y spryimannia khudozhnoho obrazu v kontsertnomu tryptykhu «V ispanskomu styli» Anatoliia Biloshytskoho. Molodyi vchenyi. № 3, pp. 634-638 [in Ukrainian].

3. Dvuzhilnaya, I.F. (2002). Novaya prostota kak fenomen muzykalnogo iskusstva vtoroy poloviny $\mathrm{KhKh} \mathrm{v}$. Aktualnye problemy mirovoy khudozhestvennoy kultury: materialy mezhdunarod. nauch. konferents., 25-26 aprelya 2002 g. Grodno. Respublika Belarus. Grodno : GrGU. V 2 ch. Ch. 1, pp. 235-239 [in Russian].

4. Kvartal Triana. URL: http://ourspain.ru/sevillasight/barriodetriana. html [in Russian].

5. Kostenko, N.Ye. (2009). Kharkovskaya domrovaya shkola v kontekste muzykalno-ispolnitelskoy kultury Ukrainy : dis. ...kand. mistetstvoznavstva : 17.00.03. Kharkiv, 270 [in Russian].

6. Matryashin, V. Detskaya syuita. URL: https://www.youtube.com/ watch ? $\mathrm{v}=$ Prk4 6 6OWfkc [in Russian].

7. Rayon Triana. URL: https://www.votpusk.ru/country/dostoprim _ info.asp? ID $=9118$ [in Russian].

8. Ruchkina, N.P. (2017). «Novaya prostota» v muzykalnom iskusstve XX - nachala XXI veka. Observatoriya kultury. T. 14, № 3, 322-329 [in Russian].

9. Teslov, D.V. (2012). Keltskaya muzyka: etapy razvitiya v tvorchestve ispolniteley-gitaristov. V mire nauki i iskusstva: voprosy filologii, iskusstvovedeniya i kulturologii: sb. st. po mater. XVII mezhdunar. nauch.-prakt. konf. Novosibirsk : SibAK, pp. 74-79 [in Russian].

10. Khorkhe, Salameya. URL: http://www.mir-dali.ru/library/ anna-dali-salvador-dali81.html [in Russian]. 